\title{
Correction to: Optimization of Bridges Reinforcement by Conversion to Tied Arch Using an Animal Migration Algorithm
}

\author{
Andrés Morales, Broderick Crawford, Ricardo Soto, \\ José Lemus-Romani, Gino Astorga, Agustín Salas-Fernández, \\ and José-Miguel Rubio
}

\section{Correction to:}

Chapter "Optimization of Bridges Reinforcement by Conversion to Tied Arch Using an Animal Migration Algorithm" in: F. Wotawa et al. (Eds.): Advances and Trends in Artificial Intelligence, LNAI 11606, https://doi.org/10.1007/978-3-030-22999-3_70

In the original version the affiliations of the editors were not correct. This has been now corrected.

The affiliation of editor José-Miguel Rubio is as follows: José-Miguel Rubio, Universidad Bernardo O’Higgins, Santiago, Chile. 